JPH: Jurnal Pembaharuan Hukum

Volume 8, Number 2, August 2021

\title{
THE LEGAL RESPONSIBILITY OF DEBTOR TO PAYMENT CURATORS IN BANKRUPTCY SITUATION
}

\author{
Didi Sukardi \\ Sheikh Nurjati State Islamic Institute Cirebon \\ didisukardimubarrak@gmail.com
}

\begin{abstract}
The Law on Bankruptcy and the Obligation to Postpone Debt Payment does not explicitly stipulate that the obligation to pay the Curator's fee is borne by the Applicant, the Debtor or the Applicant and the Debtor jointly. The obligation to pay the curator fee is imposed through the determination of the Court of Judges who decides the bankruptcy case on the Curator's Application based on the details submitted by the Curator after hearing the considerations of the Supervisory Judge. The approach method used is a normative juridical approach the curator fees. according to Act No. 37 of 2004 concerning Bankruptcy and the Obligation to Postpone Debt Payment is not absolute, because the obligation to pay the Curator's fee can be imposed on the Applicant for the Declaration of Bankruptcy, the Bankrupt Debtor, or on the Petitioner for the Declaration of Bankruptcy and the Debtor for Bankruptcy jointly through the Determination of the Panel of Judges who decides the Bankruptcy Application.
\end{abstract}

Keywords : Curators; Legal Responsibility; Payment.

\section{A. INTRODUCTION}

In the development of globalization greatly affects aspects of human life, especially in the economic and legal fields. ${ }^{1}$ The Bank serves as a Financial Intermediary with its main efforts to collect and channel public funds and provide other services that are commonly conducted by Banks in payment traffic. Both functions cannot be separated. As a business entity, the Bank always tries to gain the maximum profit from its business. ${ }^{2}$ We remember that the legal politics of making regulations at that time was as a rule to overcome an economic crisis in 1997-1998. As a rule that replaces the previous regulation, Law No. 37 of 2004 is expected to apply to overcome all economic problems in the investment, capital market and credit activities of Indonesian companies. ${ }^{3}$

To overcome the problems that arise in the business world that goes bankrupt and will also result in not being able to fulfill obligations that are

1 Anis Mashdurohatun \& Nilna Kamaliya, Legal Protection Of Consumer Reviews In Social Media Based On Local Wisdom Values, International Journal of Advanced Science and Technology, Vol. 29, No. 6, (2020), page.1511-1519

2 Anis Mashdurohatun, Ideal Construction On Credit Agreement With Fiduciary Guarantee Based On Justice Value, TEST Engineering \& Management, March-April 2020, page.27602765

3 Izzy Al Kautsar, Danang Wahyu Muhammad, Urgensi Pembaharuan Asas-Asas Hukum Pada Undang-Undang No 37 Tahun 2004 Berdasarkan Teori Keadilan Distributif, Jurnal Panorama Hukum, Vol. 5 No. 2 December 2020, page.182-192 
already due, the government makes changes to the legislation, namely by revising the existing Bankruptcy Law. ${ }^{4}$

The system used in amending the Bankruptcy Law is not to make changes in total, but only to change certain articles that need to be changed and add various new provisions to the existing Law. ${ }^{5}$ With the development of time, in this case the need for changes to the Law by improving, adding, and removing provisions that are no longer in accordance with the needs and developments of law in society, the idea arose to change the existing Law into Law No. 2004 Concerning Bankruptcy and Suspension of Debt Payment Obligations.

Bankruptcy is a general confiscation of all assets of the Bankrupt Debtor whose management and settlement is carried out by the Curator under the supervision of the Supervisory Judge. Bankruptcy assets will be distributed according to the portion of the creditor's claim. This principle of bankruptcy is a realization of the provisions of Article 1131 and the Civil Code, namely that the debtor's property becomes a joint guarantee for all creditors divided according to the principle of balance or "pari pasu prorata parte". ${ }^{6}$

Based on the provisions in the Articles above, it is clear that if the Debtor is negligent in fulfilling his obligations or achievements, the Creditor is given the right to conduct an auction of the Debtor's assets. The proceeds of the sale (auction) must be divided honestly and equally among the creditors in accordance with the balance of the amount of their respective receivables. In general, bankruptcy is related to debtor's debt or creditor's receivables. A creditor may have more than one receivable or claim, and the different receivables or claims are required differently in the bankruptcy process. $^{7}$

A company that is declared bankrupt at this time will have a bad impact and influence not only on the company but also globally. Therefore, bankruptcy institutions are one of the basic needs in business activities because the existence of bankruptcy status is one of the reasons why business people leave the market. Once entering the market, business people play in the market. If business people are no longer able to play in the market arena, they can leave the market or be forced or even forced to leave the market. In cases like this, the bankruptcy institution plays a role. ${ }^{8}$

With the decline in national economic life, it is certain that many businesses will collapse and fall so that they cannot continue their activities, including fulfilling their obligations to creditors. The collapse will cause big problems if the existing rules of the game are not complete and perfect, for

4 Dedy Tri Hartono, Perlindungan Hukum Kreditor Berdasarkan Undang-Undang Kepailitan, Jurnal IImu Hukum Legal Opinion, Edisi I, Volume 4, 2016, page.1-9

5 Imran Nating, Peranan Dan Tanggung Jawab Kurator Dalam Pengurusan Dan Pemberesan Kepailitan, Raja Grafindo Persada, Jakarta, 2005, page.7-8.

6 Jerry Hoff, Undang Undang Kepailitan Indonesia, Penerjemah Kartini Mulyadi, Tatanusa, Jakarta, 2000, page.13

7 Sutan Remy Sjahdeini, Hukum Kepailitan (Memahami faillissementsverordening Juncto Undang-Undang No. 4 Tahun 1998), Pustaka Utama Grafiti, Jakarta, 2002, page. 89.

8 Rahayu Hartini, Edisi Revisi Hukum Kepailitan, UMM Press, Malang, 2007, page. 3. 
that there needs to be rules of the game that can be used quickly, openly and effectively so as to provide opportunities for Creditors and Debtors to seek a fair settlement. ${ }^{9}$

The terms of bankruptcy based on the provisions of Article 2 paragraph (1) of the Law on Bankruptcy and Suspension of Debt Payment Obligations stipulates that a debtor who has two or more creditors and does not pay off at least one debt that has matured and is collectible, is declared bankrupt by a court decision, either at his own request or at the request of one or more creditors. Based on these provisions, it can be concluded that there are 3 (three) conditions for bankruptcy: namely (1) there must be debt; (2) one of the debts has had sufficient time and can be collected; and (3) the debtor has at least two or more creditors. The conditions for bankruptcy as regulated in Article 2 paragraph (1) of the Law on Bankruptcy and Suspension of Debt Payment Obligations are indeed very simple. Debtors with the ability to pay debts can be bankrupted by the court when all three conditions for bankruptcy are normatively met. ${ }^{10}$

Regulations regarding bankruptcy and postponement of debt repayment obligations are one of the legal products that aim to ensure certainty, order, enforcement and protection of laws that contain justice and truth that are needed today to support national economic development. The main objective is to provide a balance between Creditors and Debtors facing bankruptcy problems, providing certainty of the process, both regarding time, procedures, responsibility for managing bankrupt assets and facilitating the settlement of debts and receivables quickly, fairly, openly and effectively. ${ }^{11}$

The government's realization and action to protect the rights of parties related to bankruptcy matters is to revise the Bankruptcy Law as stipulated in the Staatsblaad of 1905 Number 217 in conjunction with the Staatsblaad of 1906 Number 348 to become a Government Regulation in Lieu of Law (Perpu) Number 1 of 1998 concerning Amendments to the Bankruptcy Law issued on April 22, 1998. On September 9, 1998 Perpu Number 1 of 1998 was passed into Act No. 4 of 1998 concerning Amendments to the Bankruptcy Law into Law, finally on October 18, 2004 Act No. 4 of 1998 was changed to Act No. 37 of 2004 concerning Bankruptcy and Suspension of Debt Payment Obligations.

The main purpose of the amendment is to provide a balance between Debtors and Creditors in dealing with bankruptcy problems, to provide process certainty, both regarding time, procedures, responsibility for managing bankrupt assets and facilitating the settlement of debts and receivables quickly, fairly, openly and effectively. ${ }^{12}$ The dispute of opinion

9 Ahmada Yani \& Gunawan Widjaja, Seri Hukum Bisnis Kepailitan, Raja Grafindo Persada, Jakarta, 1999, page. 2.

10 Tata Wijayanta, Kajian Tentang Pengaturan Syarat Kepailitan menurut Undang-Undang Nomor 37 Tahun 2004, Mimbar Hukum, Volume 26 No 1 February 2014, page.1-13

11 Widjanarko, Dampak Implementasi Undang-Undang Kepailitan Terhadap Sektor Perbankan, Jurnal Hukum Bisnis, Volume 8, 1999, page.73.

12 Bernadete Waluyo, Hukum Kepailitan dan Penundaan Pembayaran Utang, Cetakan I, Mandar Maju, Bandung, 1999, page.5. 
regarding the debt and must be proven in a simple manner resulted in the Decision on the Declaration of Bankruptcy which was handed down by the Commercial Court at the District Court to be annulled by the Supreme Court, so that the Bankrupt Debtor refused to carry out its legal obligations in providing the Curator fee that had been determined by the Commercial Court. In addition, the Debtor also filed a legal action for a judicial review of the determination of the Commercial Court regarding the Curator fee, which was later granted by the Supreme Court.

The purpose of this study is to examine and determine the legal obligations of the Bankrupt Debtor to the payment of the Curator's fee according to Act No. 37 of 2004 concerning Bankruptcy and Suspension of Debt Payment Obligations.

\section{B. RESEARCH METHODS}

The approach method using normative juridical or legal research with a normative doctrinal approach, or normative juridical legal research or normative legal research is basically an activity that will examine internal aspects (to solve problems that exist in) positive law. ${ }^{13}$ On the one hand, the science of law with its original character as a normative science and on the other hand the science of law has empirical aspects. The empirical side is the study of empirical legal science such as sociological jurisprudence, and socio legal jurisprudence. Thus, from this point of view, normative jurisprudence has a unique method of study. Empirical law can be studied through quantitative or qualitative research. ${ }^{14}$

\section{RESULT AND DISCUSSION}

\section{Payment Curators in Bankruptcy}

When entering the world of commerce, if the debtor is unable or unwilling to pay his debts to creditors (caused by a difficult economic situation or forced circumstances), the debtor can apply for a Suspension of Debt Payment Obligations to resolve the issue. It is also possible for the debtor or creditor to apply for a declaration of bankruptcy in the hope that the negligent debtor is declared bankrupt by the judge through his decision. Bankruptcy is a civil law institution as a realization of the two main principles contained in Article 1131 and Article 1132 of the Civil Code. ${ }^{15}$

Bankruptcy is a general confiscation of all assets belonging to the Debtor whose management and settlement is carried out by the Curator. According to Act No. 37 of 2004 concerning Bankruptcy and

13 Kornelius Benuf, Muhamad Azhar, Metodologi Penelitian Hukum sebagai Instrumen Mengurai Permasalahan Hukum Kontemporer, Jurnal Gema Keadilan, Volume 7 Edisi I, June 2020, page.20-33

14 Laurensius Arliman S, Peranan Metodologi Penelitian Hukum Di Dalam Perkembangan Ilmu Hukum di Indonesia, Soumatera Law Review, Vol 1, No 1, 2018, page.112-132

15 Niru Anita Sinaga, Nunuk Sulisrudatin, Hukum Kepailitan dan Permasalahannya di Indonesia, Jurnal Ilmiah Hukum Dirgantara-Fakultas Hukum Universitas Dirgantara Marsekal Suryadarma, Volume 7 No. 1, September 2016, page.158-173 
Postponement of Debt Payment Obligations, the Curator is entitled to a fee for all work that is the duty and responsibility of the Curator.

Article 13 paragraph (1) of Act No. 37 of 2004 concerning Bankruptcy and Suspension of Debt Payment Obligations stipulates that in the Decision on the Declaration of Bankruptcy must be appointed:

a. A Supervisory Judge appointed from the Court Judge.

b. Curator

If an Application for Declaration of Bankruptcy is granted by the Commercial Court, then the administrative and liquidation arrangements will be continued by the Curator. ${ }^{16}$ The curator is not a corporate organ or corporate debtor, the curator is not subject to the Indonesian Limited Liability Company Law. However, if the Curator continues the Debtor's business activities, he has an obligation to prepare, keep and issue annual financial reports. ${ }^{17}$

According to article 1 number (1) of the Bankruptcy Law, it is stated that the curator consists of 2 (two) curators, namely the Government curator, namely the Balai Harta Peninggalan and an individual curator appointed by the Court or private curator. The curator is a party who plays an important role in a bankruptcy case process, because the curator is in charge of carrying out the management and settlement of bankrupt assets. As a curator, both the government and the private sector, it is demanded that there should be no conflict of interest in carrying out their duties. Curator must act independently. ${ }^{18}$

In the Bankruptcy Law Article 69 number 1 stipulates that the task of the Curator is to manage and/or settle the bankruptcy estate. The regulation does not contain further explanations related to what is meant by "management of bankrupt assets" or "settlement of bankrupt assets", as stated in the explanation of the article with "sufficiently clear". as regulated in Article 16 paragraph (1) of Act No. 37 of 2004 concerning Bankruptcy and the Obligation to Postpone Payment which states: "The curator is authorized to carry out the task of managing and/or settling bankruptcy assets from the date the bankruptcy decision is pronounced even though an appeal is filed against the decision or Judicial review".

In carrying out its duties and responsibilities, the Curator is entitled to a service fee or fee, the amount of which is determined after the end of the bankruptcy, whether it ends with reconciliation, settlement or revocation or cancellation of the bankruptcy. Act No. 37 of 2004 concerning Bankruptcy and Obligation to Postpone Debt Payments authorizes the Minister whose scope of duties and responsibilities is in the field of law and legislation to issue regulations regarding the amount of service fees that must be paid to the Curator.

16 Imran Nating, Op.Cit, page.58.

17 Jerry hoff, Op.Cit, page.66.

18 Arkisman, Pelaksanaan Tugas Kurator Dalam Mengurus Harta Pailit Berdasarkan Pasal 72 Undang-Undang No. 37 Tahun 2004 Tentang Kepailitan Dan Penundaan Kewajiban Pembayaran Utang, Jurnal Pro Hukum, Vol. IV, No. 1, June 2015, page.7-12 
From the formulation of Article 76 of Act No. 37 of 2004 concerning Bankruptcy and Obligation to Postpone Debt Payments, the Minister whose scope of duties and responsibilities is in the field of law and legislation is given the authority to make regulations to the extent of the fees to be paid to the Curator, Article 76 of Act No. 37 of 2004 concerning Bankruptcy and Obligation to Postpone Debt Payment does not give authority to the minister whose scope of duties and responsibilities in the field of law and legislation to regulate the Curator fee is charged to the Bankrupt Applicant or Bankrupt Debtor.

The determination of the curator fee that is not requested by the bankrupt debtor certainly exceeds the demands of the bankrupt debtor, where the inclusion of a curator fee that is not requested in the posita is not an ultra petita decision considering that the determination of the curator fee is a mandate in the laws and regulations. ${ }^{19}$

Since the Government Regulation in Lieu of Act No. 1 of 1998 concerning Amendments to the Law on Bankruptcy, which was later stipulated into Law based on Act No. 4 of 1998 concerning Bankruptcy, the regulation on compensation for services for Curators is based on a Decree of the Minister of Justice of the Republic of Indonesia. Indonesia Number M.09-HT 05.10 of 1998 concerning Guidelines for the Amount of Fees for Curators and Management and these regulations are still valid after the enactment of Act No. 37 of 2004 concerning Bankruptcy and Obligations to Delay Payment of Debts.

On January 11, 2013, the Minister of Law and Human Rights issued Regulation of the Minister of Law and Human Rights Number 1 of 2013 concerning Guidelines for Rewards for Curators and Administrators, Regulation of the Minister of Law and Human Rights No: 1 of 2013 replaced the Decree of the Minister of Justice of the Republic of Indonesia. Indonesia Number M.09-HT 05.10 of 1998.

Decree of the Minister of Justice Number: M.09-HT.05.10 of 1998 concerning Guidelines for the Amount of Fees for Curators and Management and Regulation of the Minister of Law and Human Rights No. 1 of 2013 concerning Guidelines for Rewards for Curators and Management, it can be seen that the amount of curator service fees for each of these regulations is different from one another. This can be seen in the provisions of Article 17 paragraph (2) and paragraph (3) of the Bankruptcy Law and Postponement of Debt Payment Obligations which states that "paragraph (2): The panel of judges that annuls the bankruptcy declaration decision also determines the bankruptcy fee and curator fee. ; paragraph (3): The fees as referred to in paragraph (2) are charged to the applicant for the declaration of bankruptcy or to the applicant and debtor in the comparison determined by the panel of judges". The amount of fee for curator services based on this provision is

19 Haposan Sialagan, Masalah Putusan Ultra Petita dalam Pengujian Undang-Undang, Jurnal Mimbar Hukum, Vol. 22 No. 1, February 2010, page.74. 
charged to two parties, namely the bankruptcy applicant and the bankrupt debtor. ${ }^{20}$

The difference between the Decree of the Minister of Justice of the Republic of Indonesia Number M.09-HT 05.10 of 1998 and the Regulation of the Minister of Law and Human Rights Number 1 of 2013 is in the Decree of the Minister of Justice of the Republic of Indonesia Number M.09-HT 05.10 of 1998 if there is no bankruptcy fee Curator calculated based on hours worked and borne by the Debtor. Meanwhile, in the Regulation of the Minister of Law and Human Rights Number 1 of 2013 if there is no bankruptcy fee is calculated based on working hours and is borne by the Bankrupt Applicant.

In the event that the bankruptcy declaration decision is canceled as a result of a cassation or reconsideration, the Panel of Judges which annuls the bankruptcy decision also determines the bankruptcy fees and curator fees to be charged to the petitioner for the declaration of bankruptcy or to the petitioner and the debtor in the comparison determined by the panel of judges as stipulated in Article 17 paragraphs (2) and (3) of Act No. 37 of 2004 concerning Bankruptcy and Suspension of Debt Payment Obligations.

Act No. 37 of 2004 concerning Bankruptcy and Postponement of Debt Payment Obligations does not explicitly state that the Curator fee is charged to the Bankrupt Applicant, Debtor or to the Bankrupt Petitioner and Debtor, but instead gives full authority to the Panel of Judges who decides on the Declaration of Bankruptcy or the Panel of Judges who decides to declare bankruptcy cancel the Decision on the Declaration of Bankruptcy at the level of Cassation and Review to charge the Curator fee.

From the formulation of Article 17 paragraph (3) of Act No. 37 of 2004 concerning Bankruptcy and Postponement of Debt Payment Obligations related to the Lex Superior Derogat Legi Inferiori principle, the Minister of Law and Human Rights Regulation Number 1 of 2013 must be set aside, because the regulation is contrary to Act No. 37 of 2004 concerning Bankruptcy and the Obligation to Postpone Debt Payments.

Injustice and completely different conditions can be caused by the provisions of Article 17 paragraph (3) of Act No. 37 of 2004 concerning Bankruptcy and Obligations to Delay Debt Payments and Article 2 paragraph (1) letter (c) of the Minister of Law and Human Rights Number 1 of 2013 is if the party who becomes the Applicant for Bankruptcy is the Creditor Party and the creditor is the losing party in the Cassation or Review level, if it is based on the provisions of Article 17 paragraph (3) of Act No. 37 of 2004 concerning Bankruptcy and the Obligation to Delay in Payment of Debt can be held responsible together with the Debtor to pay the Curator's fee after the cancellation of

20 Sukses M. P. Siburian, Hak dan Kewajiban Kurator Pasca Putusan Pembatalan Pailit Pada Tingkat Kasasi Oleh Mahkamah Agung (Studi Kasus Kepailitan PT. Telkomsel VS PT. Prima Jaya Informatika), USU Law Journal, Vol.3.No.1 April 2015, page.151 
Bankruptcy by the Supreme Court, whereas based on Article 2 paragraph (1) letter (c) Permenkumham Number 1 of 2013 the Creditor who is the losing party and acts as the applicant for the declaration of bankruptcy is the party who are definitely responsible for paying the Curator's fees there has been an annulment of the bankruptcy status by the Supreme Court.

Article 2 of Act No. 37 of 2004 concerning Bankruptcy and Obligation to Postpone Debt Payments Applications for Bankruptcy Statements, apart from being submitted by Creditors and Debtors, can also be filed by the Attorney General's Office, Bank Indonesia, the Capital Market Supervisory Agency and the Minister of Finance. If it is based on article 2 paragraph (1) letter (c) Permenkumham Number 1 of 2013 the Prosecutor's Office, Bank Indonesia, the Capital Market Supervisory Agency and the Minister of Finance acting as the Applicant for the Declaration of Bankruptcy must be responsible for providing compensation for Curator services in the event of cancellation of the bankruptcy status by the Court. Supreme Court because the Prosecutor's Office, Bank Indonesia, the Capital Market Supervisory Agency and the Minister of Finance act as Petitioners for the Declaration of Bankruptcy, whereas according to the provisions of Article 17 paragraph (3) Article 2 of Act No. 37 of 2004 concerning Bankruptcy and Obligation to Postpone Debt Payments, if the Prosecutor's Office, the Bank Indonesia, the Capital Market Supervisory Agency and the Minister of Finance act as Petitioners for the Declaration of Bankruptcy and there has been an cancellation of the bankruptcy status by the Supreme Court, although Creditors cannot be held responsible for paying Curator fees but Debtors who have an interest in bankruptcy cases can be charged with being responsible for paying to Curator.

After the Bankruptcy process ends, whether it ends with reconciliation, settlement or cancellation or cancellation of the bankruptcy, the Curator is still entitled to receive compensation for the work and responsibilities that the Curator has done. This is due to the fact that the Curator's duties begin when the decision to declare bankruptcy is pronounced by the Commercial Court at the District Court, even though legal action is taken against the decision of the Bankruptcy Application, both cassation and judicial review. In addition, all actions taken by the Curator remain valid and binding before the Curator receives the notification of the bankruptcy cancellation.

The curator has a difficult task in this regard, because on the one hand he must immediately go to the field to make an inventory of bankrupt assets/assets because no later than two days after the bankruptcy decision is received, he must immediately make a record of the bankruptcy assets as regulated in Article 100 paragraph (1) of the Law. Act No. 37 of 2004 concerning Bankruptcy and the Obligation to Postpone Debt Payments, on the other hand, it is still necessary to think about announcing the bankruptcy declaration decision within a period of no later than five days as regulated in Article 15 paragraph (4) of Act No. 
37 of 2004 concerning Bankruptcy and Liability Delay in Payment of Debt, where the notification from the newspaper appointed by the Supervisory Judge has not been received. High dedication and professionalism of the Curator in carrying out his duties is the key so that everything can run according to the provisions.

Act No. 37 of 2004 concerning Bankruptcy and the Obligation to Postpone Debt Payment does not explicitly stipulate that the obligation to pay the Curator's fee is borne by the Applicant, the Debtor or the Applicant and the Debtor jointly. The obligation to pay the curator fee is imposed through the stipulation of the Panel of Judges of the Court which decides the bankruptcy case on the Curator's Application based on the details submitted by the Curator after hearing the considerations of the Supervisory Judge.

The determination of the Curator's fee if the bankruptcy ends due to a decision on cassation or review which annuls the previous bankruptcy decision must be based on Article 17 of the Bankruptcy Act If the article is compared with the similar provisions in the previous Act No. 37 of 2004 concerning Bankruptcy and Suspension of Debt Payment Obligations, namely Article 14 paragraph (3) of the Bankruptcy Law concerning the Stipulation of Perppu No. 1 of 1998 concerning the Amendment of the Bankruptcy Law into Law, which states as follows: "The court that decides on the cancellation of the bankruptcy declaration decision must determine the bankruptcy fee; The court imposes these costs on those who have submitted a petition for a declaration of bankruptcy, to the debtor, or to both according to the balance determined by the judge. There is no legal remedy against this decision." ${ }^{\prime 21}$

\section{Responsibility of The Curator In The Distribution of Bankrupt Assets}

Bankruptcy law in principle is a collective action to get debts repaid and not a pure dispute resolution, so it is not like a dispute resolution process in civil procedural law. Bankruptcy cases are very different from civil cases, the meaning of the sentence is proven simply in Article 6 paragraph 3 of the old Bankruptcy Law cannot be applied with "Bewijsvoering" in civil cases. "Bewijsvoering" itself has the understanding that evidence is to confirm the arguments of the lawsuit. In a civil dispute, if the Defendant discloses the Plaintiff's arguments, the Plaintiff must conduct Bewijsvoering. If a provision of the Act such as Article 6 paragraph 3 of the old Bankruptcy Law only contained a general and normative formulation, its concrete application depends on the judge's interpretation of a certain legal rule. The conclusion is that the judge must state what is the meaning of the ratio and the basis for consideration of the decision.

21 Fazlur Rahman, Prinsip Keadilan Dalam Penetapan Imbalan Jasa Kurator Jika Putusan Pailit Dibatalkan (Studi Putusan Kasus Kepailitan PT Telekomunikasi Selular), Jurnal Hukum, Vol 1 No. 1, 2014, page.9-10 
The duties and authorities of the curator are relatively heavy, as stated in Article 69 paragraph (1) of Act No. 37 of 2004 that the task of the curator is to manage and/or settle bankrupt assets. It is further stated in Article 15 paragraph (3) of Act No. 37 of 2004 that the curator must be independent, have no conflict of interest with debtors or creditors, and is not currently handling bankruptcy cases and delays in paying debt obligations for more than 3 (three) cases. What is meant by "independent and has no conflict of interest" is that the continuity of the curator's existence does not depend on the debtor or creditor, and the curator does not have the same economic interest as the economic interest of the debtor or creditor. According to Sutan Remy Sjahdeini, a conflict of interest is deemed to have occurred if the following things occur, among others: :

a. The curator becomes one of the creditors;

b. The curator has a family relationship with the controlling shareholder or management of the debtor company;

c. The curator owns more than $10 \%$ shares in one of the creditor companies or in the debtor company;

d. Curator is an employee, member of the Board of Directors, or member of the Board of Commissioners of a creditor company or debtor liability company. ${ }^{22}$

In connection with the case process in the Commercial Court, Article 284 (1) of the Bankruptcy Act No. 4 of 1998 which was later replaced by Act No. 37 of 2004, Act No. 37 of 2004 concerning Bankruptcy and the Obligation to Postpone Debt Payments in Article 299 stipulates whereas the applicable civil procedural law is also applied to the Commercial Court, unless otherwise stipulated by Act No. 37 of 2004 concerning Bankruptcy and Obligation to Postpone Debt Payments.

The task of the Curator begins when the decision to declare Bankruptcy is pronounced by the Commercial Court, on that basis the Curator is still entitled to receive a fee/compensation for services even though the decision on the Bankrupt Application is later annulled by the Supreme Court. In order to fulfill the sense of justice for the Curator to receive compensation for services, the Bankruptcy Law provides a special arrangement (lex Specialist) relating to the Commercial Court Determination regarding the Curator fee, namely through the provisions of Article 91 of Act No. 37 of 2004 concerning Bankruptcy and the Obligation of Suspension. Debt Payment.

In principle, the curator has the authority to manage and settle bankrupt assets since the decision to declare bankruptcy was issued from the Commercial Court, even though legal action is filed against the decision, namely an appeal as stipulated in Article 16 paragraph (1) of Act No. 37 of 2004. This is a legal consequence from the nature of 
"immediately" (uitvoorbaar bij voorraad) of the bankruptcy declaration decision as stipulated in Article 8 paragraph (7) of Act No. 37 of 2004. ${ }^{23}$

The important thing that must be considered by the curator in carrying out his duties is that not all authorities can be carried out independently. In fact, it is highly recommended that in all activities the curator is considered important, he must consult with or even with the approval of the supervisory judge, including on matters not regulated by law to request consultation and approval from the supervisory judge. ${ }^{24}$

A curator in carrying out his duties is not allowed to take arbitrary actions that pass through the corridors of his law and needs to pay attention to several things, namely whether he has the authority to carry out such actions, then whether his actions are in accordance with the right circumstances and conditions by taking into account economic and business factors. ${ }^{25}$

In a bankruptcy estate settlement, it is possible for more than one curator to manage said assets, thus the possibility arises that the curators cannot reach a unanimous agreement on a matter, thus Article 73 paragraph (1) stipulates that if more than one curator is appointed then to carry out a legal and binding act, curators need the approval of more than half the number of curators. ${ }^{26}$

The Curator's responsibilities can be explained in detail with the implementation of tasks, including the following: ${ }^{27}$

a. Announce the decision on bankruptcy declaration, place and time of holding the first meeting of Creditors in the State Gazette of the Republic of Indonesia and in two daily newspapers determined by the Supervisory Judge, within a period of no later than 5 (five) days from the date the decision on the bankruptcy declaration is received (Article 15 paragraph (4) Bankruptcy Act);

b. Ensure the safety of the bankruptcy estate by keeping all letters, documents, money, jewelry, securities and other securities by providing a receipt (Article 98 of the Bankruptcy Law);

c. Make a record of bankruptcy assets no later than 2 (two) days after receiving the decision letter on his appointment as Curator (Article 100 of the Bankruptcy Law), and after that must make a list of the nature and amount of receivables and the amount of their respective receivables (Article 102 Bankruptcy Act). The registration of the

23 Dewi Tuti Muryati, Dhian Septiandani, Efy Yulistyowati, Pengaturan Tanggung Jawab Kurator Terhadap Pengurusan dan Pemberesan Harta Pailit Dalam Kaitannya Dengan Hak Kreditor Separatis, Jurnal Dinamika Sosial Budaya, Volume 19, Nomor 1, June 2017, page.11-21

24 Munir Fuady, Hukum Pailit dalam Teori dan Praktek, Citra Aditya Bakti, Bandung, 2014, page. 50

25 Muhammad Syeisar Nanda Prawira, Suratman, Faisol, Pertanggungjawaban Kurator Karena Menyebabkan Timbulnya Kerugian Dalam Pemberesan Harta Pailit, Dinamika Jurnal Ilmiah Hukum, Vol 27, No 5, January 2021, page.662-678

26 Sutan Remy Sjahdeini, Hukum Kepailitan Memahami Undang-undang No. 37 Tahun 2004 Tentang Kepailitan, PT. Pustaka Utama Grafiti, Jakarta, 2010, page. 211

27 Moch Zulkarnain Al Mufti, Tanggung Jawab Kurator dalam Penjualan Harta Pailit di Bawah Harga Pasar, Lex Renaissance, No. 1 Vol. 1 January 2016, page.92-106 
bankruptcy estate as referred to in Article 100 and the register as referred to in Article 102 must be placed in the Registrar's Office for the Court to be seen by everyone free of charge (Article 103 of the Bankruptcy Law);

d. Announce in two daily newspapers the deadline for submitting creditors' claims, the day, date, time, and place of the debt matching meeting, which is determined by the Supervisory Judge (Article 114 of the Bankruptcy Law);

e. Matching incoming invoices (Article 116 of the Bankruptcy Law);

f. Make a list of receivables that are temporarily recognized and denied (Article 117 of the Bankruptcy Law);

g. Provide at the Registrar's Office a copy of the list of claims temporarily recognized and temporarily disputed (Article 119 of the Bankruptcy Law);

h. Notify creditors of the existence of a list of receivables that are temporarily recognized and temporarily disputed, as well as summoning them to attend the receivables verification meeting (Article 120 of the Bankruptcy Law);

i. Provide a report on the condition of the bankrupt assets, after the meeting of the verification of receivables ends (Article 143 paragraph (1) of the Bankruptcy Law);

j. Provide written opinion on the peace plan (Article 146 of the Bankruptcy Law);

k. Make/compile a list of distributions and request approval from the Supervisory Judge (Article 189 paragraph (1) of the Bankruptcy Law) and place a list of distributions that have been approved by the Supervisory Judge at the Court Registrar's Office to be seen by Creditors during the grace period determined by the Supervisory Judge (Article 192 of the Bankruptcy Law);

I. Carry out the distribution that has been determined (Article 201 of the Bankruptcy Law);

$\mathrm{m}$. Announce the summary of the end of the bankruptcy in a newspaper appointed by the Supervisory Judge and in the State Gazette (Article 202 paragraph (2) of the Bankruptcy Law);

$\mathrm{n}$. Provide accountability regarding the management and settlement tasks that have been carried out to the Supervisory Judge (Article 202 paragraph (3) of the Bankruptcy Law).

In addition, the curator's actions are also regulated in Article 72 of the Bankruptcy Law which postulates that there is a causal relationship between the errors or omissions made by the curator and the losses caused to the bankruptcy estate. However, because Article 72 of the Bankruptcy Law does not regulate the sanctions imposed on the curator's actions that harm the bankruptcy estate, Article 1365 of the Civil Code can be used as a legal basis for determining sanctions for errors or omissions committed by the curator in connection with the task of managing and settling bankrupt assets. . Loss of bankrupt property 
caused by the curator can be requested for compensation from the curator's personal property.

\section{CONCLUSION}

The Bankrupt Debtor's legal obligation to pay curator fees. according to Act No. 37 of 2004 concerning Bankruptcy and the Obligation to Postpone Debt Payment is not absolute, because the obligation to pay the Curator's fee can be imposed on the Applicant for the Declaration of Bankruptcy, the Bankrupt Debtor, or on the Petitioner for the Declaration of Bankruptcy and the Debtor for Bankruptcy jointly through the Determination of the Panel of Judges who decides the Bankruptcy Application, curator in carrying out his duties is not allowed to take arbitrary actions that pass through the corridors of his law and needs to pay attention to several things, namely whether he has the authority to carry out such actions, then whether his actions are in accordance with the right circumstances and conditions.

\section{BLIBIOGRAPHY}

\section{Books :}

Ahmada Yani \& Gunawan Widjaja, 1999, Seri Hukum Bisnis Kepailitan, Raja Grafindo Persada, Jakarta;

Bernadete Waluyo, 1999, Hukum Kepailitan dan Penundaan Pembayaran Utang, Cetakan I, Mandar Maju, Bandung;

Imran Nating, 2005, Peranan Dan Tanggung Jawab Kurator Dalam Pengurusan Dan Pemberesan Kepailitan, Raja Grafindo Persada, Jakarta;

Jerry Hoff, 2000, Undang Undang Kepailitan Indonesia, Penerjemah Kartini Mulyadi, Tatanusa, Jakarta;

Munir Fuady, 2014, Hukum Pailit dalam Teori dan Praktek, Citra Aditya Bakti, Bandung;

Rahayu Hartini, 2007, Edisi Revisi Hukum Kepailitan, UMM Press, Malang;

Sutan Remy Sjahdeini, 2002, Hukum Kepailitan (Memahami faillissementsverordening Juncto Undang-Undang No. 4 Tahun 1998), Pustaka Utama Grafiti, Jakarta;

Sutan Remy Sjahdeini, 2010, Hukum Kepailitan Memahami Undang-undang No. 37 Tahun 2004 Tentang Kepailitan, PT. Pustaka Utama Grafiti, Jakarta;

\section{Journals :}

Anis Mashdurohatun, Ideal Construction On Credit Agreement With Fiduciary Guarantee Based On Justice Value, TEST Engineering \& Management, March-April 2020; 
Anis Mashdurohatun \& Nilna Kamaliya, Legal Protection Of Consumer Reviews In Social Media Based On Local Wisdom Values, International Journal of Advanced Science and Technology, Vol. 29, No. 6, (2020);

Arkisman, Pelaksanaan Tugas Kurator Dalam Mengurus Harta Pailit Berdasarkan Pasal 72 Undang-Undang No. 37 Tahun 2004 Tentang Kepailitan Dan Penundaan Kewajiban Pembayaran Utang, Jurnal Pro Hukum, Vol. IV, No. 1, June 2015;

Dedy Tri Hartono, Perlindungan Hukum Kreditor Berdasarkan Undang-Undang Kepailitan, Jurnal IImu Hukum Legal Opinion, Edisi I, Volume 4, 2016;

Dewi Tuti Muryati, Dhian Septiandani, Efy Yulistyowati, Pengaturan Tanggung Jawab Kurator Terhadap Pengurusan dan Pemberesan Harta Pailit Dalam Kaitannya Dengan Hak Kreditor Separatis, Jurnal Dinamika Sosial Budaya, Volume 19, Nomor 1, June 2017;

Fazlur Rahman, Prinsip Keadilan Dalam Penetapan Imbalan Jasa Kurator Jika Putusan Pailit Dibatalkan (Studi Putusan Kasus Kepailitan PT Telekomunikasi Selular), Jurnal Hukum, Vol 1 No. 1, 2014;

Haposan Sialagan, Masalah Putusan Ultra Petita dalam Pengujian UndangUndang, Jurnal Mimbar Hukum, Vol. 22 No. 1, February 2010;

Izzy Al Kautsar, Danang Wahyu Muhammad, Urgensi Pembaharuan Asas-Asas Hukum Pada Undang-Undang No 37 Tahun 2004 Berdasarkan Teori Keadilan Distributif, Jurnal Panorama Hukum, Vol. 5 No. 2 December 2020;

Kornelius Benuf, Muhamad Azhar, Metodologi Penelitian Hukum sebagai Instrumen Mengurai Permasalahan Hukum Kontemporer, Jurnal Gema Keadilan, Volume 7 Edisi I, June 2020;

Laurensius Arliman S, Peranan Metodologi Penelitian Hukum Di Dalam Perkembangan Ilmu Hukum di Indonesia, Soumatera Law Review, Vol 1, No 1, 2018;

Moch Zulkarnain Al Mufti, Tanggung Jawab Kurator dalam Penjualan Harta Pailit di Bawah Harga Pasar, Lex Renaissance, No. 1 Vol. 1 January 2016;

Muhammad Syeisar Nanda Prawira, Suratman, Faisol, Pertanggungjawaban Kurator Karena Menyebabkan Timbulnya Kerugian Dalam Pemberesan Harta Pailit, Dinamika Jurnal IImiah Hukum, Vol 27, No 5, January 2021;

Niru Anita Sinaga, Nunuk Sulisrudatin, Hukum Kepailitan dan Permasalahannya di Indonesia, Jurnal Ilmiah Hukum Dirgantara-Fakultas Hukum Universitas Dirgantara Marsekal Suryadarma, Volume 7 No. 1, September 2016; 
Sukses M. P. Siburian, Hak dan Kewajiban Kurator Pasca Putusan Pembatalan Pailit Pada Tingkat Kasasi Oleh Mahkamah Agung (Studi Kasus Kepailitan PT. Telkomsel VS PT. Prima Jaya Informatika), USU Law Journal, Vol.3.No.1 (April 2015);

Tata Wijayanta, Kajian Tentang Pengaturan Syarat Kepailitan menurut UndangUndang Nomor 37 Tahun 2004, Mimbar Hukum, Volume 26 No 1 February 2014;

Widjanarko, Dampak Implementasi Undang-Undang Kepailitan Terhadap Sektor Perbankan, Jurnal Hukum Bisnis, Volume 8 1999;

\section{Regulations:}

Act No. 37 of 2004 concerning Bankruptcy and Suspension of Debt Payment Obligations;

Decree of The Minister of Justice of The Republic of Indonesia Number : M.09HT.05.10 of 1998 Concerning Guidelines For The Amount of Services Rewards For Curators and Management;

Regulation of the Minister of Law and Human Rights No. 1 of 2013 concerning Guidelines for Rewards for Curators and Management; 